\title{
Spatial Transformation as an Institutional Factor of the Public Management of Macroeconomic Systems
}

\author{
Submitted 04/01/19, 1st revision 26/01/19, 2nd revision 17/04/19, accepted 27/05/19 \\ Voskanov, M.E. ${ }^{1}$, Ivanova, E.A. ${ }^{2}$, Ponomareva, M.A. ${ }^{3}$, Medvedev, R.V. ${ }^{4}$
}

\begin{abstract}
:
Purpose: The article analyzes the issue of substantiating the impact of the spatial organization of the territory of the Russian Federation on the public management at the level of macroeconomic systems.

Design/Methodology/Approach: The federal districts were chosen as the object of the study as macro-regional socio-economic systems, the Southern Federal District and its constituent regions (subjects of the Russian Federation). The article investigates the main transformational processes taking place in the RF spatial development, concerning the development of the regional systems of the public management and the necessity of their consistency at the supra-regional (macro-regional) level.

Findings: The authors propose a set of measures to form supra-regional system to coordinate the regional development priorities considering the peculiarities of the spatial transformation of Russia's territory and the position of the Southern macro-region in the spatial system of the country. This system formation allows involving as many interested parties as possible.

Practical Implications: The results may be implemented into macro-region public administration to maximize the advantages of the geo-economic and strategic position, natural and climatic conditions of Russian regions' development.

Originality/Value: The main contribution of this study is a tailored approach to the public administration of the social and economic development of the macro-regions in the context of the spatial transformation
\end{abstract}

Keywords: Macro-region, public management, spatial transformation.

JEL code: R10, R12, R58.

Paper Type: Research article in Special Issue dedicated to Russian Economy.

Section 7: Economic Development.

${ }^{1}$ Candidate of Economics, Professor of Management, Chair, Yessentuki Institute of Management, Business and Law, Yessentuki, Russian Federation.

${ }^{2}$ Doctor of Economics, Professor, Director of the Institute of Magistracy, Rostov State

University of Economics, Rostov-on-Don, s888pe@yandex.ru

${ }^{3}$ Doctor of Economics, Professor, Chair of Economics of the Region, Industries and Enterprises, Rostov State University of Economics, Rostov-on-Don.

${ }^{4}$ Postgraduate of the Chair of Economics of the Region, Industries and Enterprises, Rostov State University of Economics, Rostov-on-Don. 


\section{Introduction}

The transformations of the social and economic macro-systems in Russia coursed by the 1990-s market reforms were accompanied with the worsening of the national economy functioning and a significant decline of the level and quality of the population life. The consequences for social and economic macro-systems were manifested in the slow economic growth, instability, and imbalance in their functioning. The terms "region" and "macro-region", "macro-system" are used in this article. Because there are number of approaches to define these notions in the literature, it is necessary to give the authors' understanding of these terms.

As a rule, region refers to the certain part of the territory, having some common social and economic peculiarities and conditions. In the scientific and educational literature regions refer to different territories possessing some common features. These can be economic regions, country's regions, uniting some economic regions, group of countries, etc. The decree of the President of the Russian Federation "On the main provisions of the regional policy in the Russian Federation" of June 3, 1996 No.803 defines a region as "a part of the territory of the Russian Federation, possessing common natural, social and economic, national and cultural and others conditions. Region can coincide with borders of the Russian Federation subject territory or unite several Russian Federation subjects".

Social and economic macro-system is a holistic localized in the economic time and space aggregate of the interconnected, interdependent and interacting social and economic institutions and relations in the context of production, distribution, exchange and consumption in the society consisting of the subsystems with common specificity of the functioning. Macro-regions in the frame of the territory of one country can be referred to the social and economic macro-systems. Considering plurality of the concept "social and economic macro-system", it is possible to single out two approaches to its definition. On the one hand, social and economic macrosystem is a natural and social, natural and territorial formation within which natural interaction of the economic subjects and processes takes place. On the other, social and economic macro-system can be an object of the administrative and territorial, political and territorial division of the state which is administered centrally.

In the Russian practice the concept "social and economic macro-system" is expedient to be applied as an inner-state category detailing to the federal districts level. Based on this is necessary to understand the social and economic macrosystems as parts of the state's territories characterized by relative homogeneity of the social and economic parameters or territorial vicinity to one of the centers, interact with other parts of the state's territory and, in some cases, have the 
managing or coordination bodies, common programs and development strategies of the federal level.

The macroeconomic system of the Southern Federal District, or the Southern macroregion, consisting of eight subjects (regions) of the Russian Federation, including Rostov Region, is selected for the research object in this article. The issue of the necessity to coordinate decisions taken at the level of the regions of the Southern macro-region with "supra-regional" nature (for example, such as major highways construction, the common transport and logistics framework formation, ecological problems solution, etc) is considered in the article. The regional strategic documents and related state programs with relevant measures, allocation of obligations, including financial ones, as well as responsibility among the parties from different regions participating in the implementation of such "supra-regional" projects are to provide such coordination

Currently the regions constituting the Southern macro-region are rather independent in working out their own strategic documents that in practice makes difficult to solve the problems beyond the competence of the regional authorities. It is due to the lack of the "full" level of management in the macro-regions, where lawmaking is not provided, there are executive bodies. Introduction of such level in the general system of the RF state government would be excessive because in fact it would become the fourth one. It would make the government system too bulky and would reduce its efficiency.

At the same time the Russian Federation spatial transformation leads to the formation of new specialization of its regions and macro-regions, which demands to implement new priorities both at regional level and macro-regional one. "Zoomed" vision of these priorities at the country level in general (from the federal centre) cannot insure the necessary level of detailing of these priorities to put them into practice in the form of concrete projects and activities and that are fixed in the corresponding regional strategic documents (development strategies and state programs setting the activities, terms and financing sources). It results in the necessity to form the flexible mechanism of the "supra-regional" coordination of the strategically significant initiatives (priorities, goals, activities, financing sources in certain regions) ensuring effective interaction of different Russian Federation subjects in the macro-economic space.

To solve this problem, it is necessary to develop the system of the public management principles at an interregional level, to attract maximum number of the parties, interested in the process of the identifying the strategic priorities of the territory development while implementing the "supra-regional" projects. 


\section{Theoretical, Informational, Empirical and Methodological Issues}

Theoretical foundations of research are based on the main public administration theories, including public management, regional and spatial economics, system analysis reflecting the necessity for the regions to interact in macroeconomic space as subjects to take decisions concerning their mutual interests. The methods of logical, comparative, retrospective analysis, induction and deduction, methods of generalization and aggregation of data, system analysis are used as the main ones. Information basis of the research is based on the official data of the Federal State Statistics Service of the Russian Federation in the context of the RF subjects and macro-regions, official federal and regional strategic documents

\section{Results}

The analysis of the literature on the macro-regional social and economic systems management shows that this issue is paid much attention both in theory and practice by the Russian public administration. The available sources on this topic can be divided into several directions:

The macro-regions are considered as the subjects of the strategic management and planning: In the frame of this direction it is necessary to single out the work by Ovsyannikova and Sharkevich (2015) where the attention is focused on intermediate position of the macro-regions between regional and national levels in a series of spatial-territorial identities, the approaches to goal setting and general strategic planning of their social and economic development taking into account this specificity. In the frame of this direction it is also worth mentioning the work by Reshiev (2009) devoted to the task of selection of the adequate methods of public regulations and encouraging the development of the macroregions and their constituting territories, providing the effective decision of the priority problems of the poorly developed territories of the South of Russia.

Some authors, taking into account the intermediate position of the macro-regions in the system of the Russian budget federalism, consider the retrospectives of the macro-regions formation in the context of the experience of the 1920s economic zoning (Ivanova et al., 2016), possibilities of the designing of the new macroeconomic model of the national economy (Kuklina and Ponomareva, 2012), the development of the diagnostics of the performance of the macroregion economy management (Gerasimov et al., 2011) and others. The separate enlarged direction is the researches of a sectoral nature applicable to macroregional systems, the works on human potential evaluation (Lokosov et al., 2018), import substitution (Belyakova et al., 2018), macro-regions foreign economic activity (Ivanov, 2012), comparative analysis of the Russian macro- 
regions in terms of social and economic development (Popov and Saraev, 2016) and others are among them.

The direction that is the most interesting in the context of this article is to research the issues of the interregional integration of the regions constituting the macro-regions, and to work out the approaches to manage its development, to identify the performance criteria of the spatial development project based on the interregional integration (Kurushina et al., 2017; Butorina, 2013), to identify the position and role of the macro-regions in the country's spatial development (Suslov, 2017; Zubarevich, 2019). It is expedient to identify the list of such "supra-regional" projects at the federal level while working out the strategic documents, the spatial development strategy.

In 2018 the Russian Federation developed a few strategic documents for the next period. The Spatial Development Strategy of the Russian Federation for the period up to 2025 (Order of the Government of the Russian Federation of February 13, 2019 No. 207-p) is among the main ones. In addition, all the RF subjects and municipalities developed their own strategies of the social and economic development. The strategy of socio-economic development of the Rostov region until 2030 is worked out and adopted in Rostov Region which a constituent of the Southern macro-region. The Southern macro-region comprises eight RF subjects: Republic of Adygea, Republic of Kalmykia, Republic of Crimea, Krasnodar Krai, Astrakhan Region, Volgograd Region, Rostov Region, Sevastopol (Figure 1).

Figure 1. The Southern macro-region map: a) in the context of the Russian Federation; b) the composition of the constituent entities of the Russian Federation of the Southern macro-region: 1 - the Republic of Adygea, 2 - the Republic of Kalmykia, 3 - Krasnodar Territory, 4 - Astrakhan Region, 5 - Volgograd Region, 6 Rostov Region, 7 - Republic of Crimea, 8 - Federal City Sevastopol .

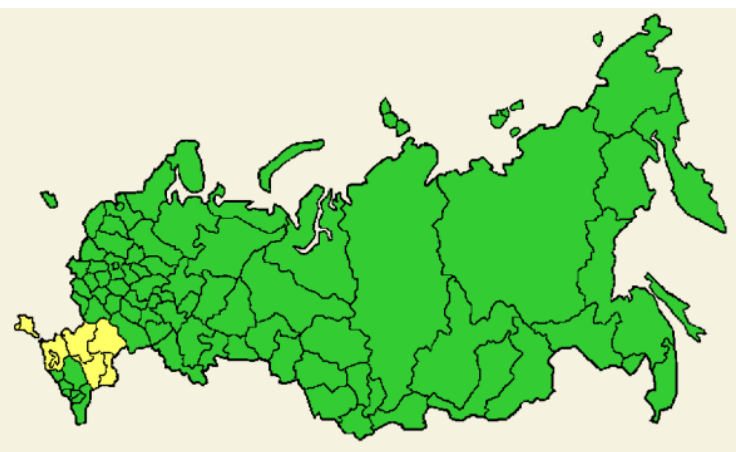

a)

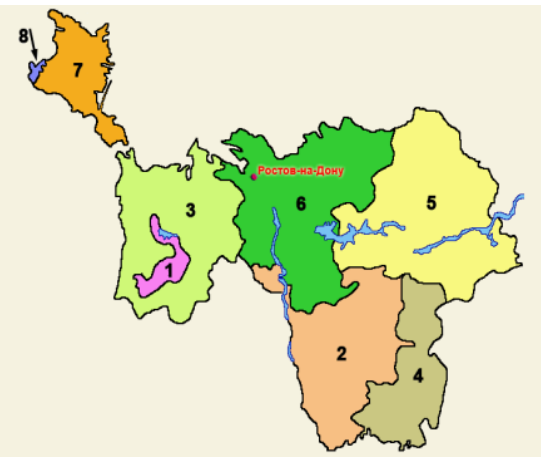

b) 


\section{Spatial Transformation as an Institutional Factor of the Public Management}

of Macroeconomic Systems

In the mentioned Spatial Developemnt Strategy it is noted that "spatial organization of the Russian Federation economy starting since 1990s has been transformed under the influence of the changing factors of the economy position, international trade and scientific and technological developemnt" Decree of the Government of the Russian Federation of February 13, 2019 No. 207-p).

In the context of this reaserch "accelerated development of the consumer goods industry in the central regions of the European part of the Russain Federation and in those Russian Federation subjects having access to the Baltic and the Black seas"; the concentration of the scientific, scientific and technical and innovative activities in the major urban agglomerations; the concentration of the agricultural production on the territories with the most favorable agricultural, climatic and soil conditions and advantageous position relative to high-capacity consumer markets" are to be singles out as the most significant and meningfull changes for the Southern macroregion (Spatial Development Strategy of the Russian Federation until 2025 // Order of the Government of the Russian Federation of February 13, 2019 No. 207-p).

It is confirmed by new specializations of the Southern macro-region's regions, whose development trends are shown the Strategy (Table 1).

Table 1. Perspective directions for the new specialization development of the Southern macro-region's regions

\begin{tabular}{|l|l|l|l|}
\hline & Region & New specialization in the context of the spatial transformation \\
\hline 1 & $\begin{array}{l}\text { Republic of } \\
\text { Adygea }\end{array}$ & $\begin{array}{l}\text { Perspective economic specialization: paper and paper products } \\
\text { production; finished metal goods production, except machines and } \\
\text { equipment; machines and equipment production, that are not included in } \\
\text { other groupings; furniture production; drinks production; clothes } \\
\text { production; food production; production of other non-metal mineral } \\
\text { products; other finished goods production; rubber and plastic items } \\
\text { production; textile goods production; chemicals and chemical products } \\
\text { production; electrical equipment production; crop and livestoc, providing } \\
\text { services in these spheres; tourism. Non-perspective economic } \\
\text { specialization critically important for the region's economy: wood } \\
\text { processing and of wood products manufacture, except furniture. }\end{array}$ \\
\hline 2 & $\begin{array}{l}\text { Republic of } \\
\text { Kalmykia }\end{array}$ & $\begin{array}{l}\text { Perspective economic specialization: clothes production; food production; } \\
\text { other finished goods production; chemicals and chemical products } \\
\text { production; crop and livestoc, providing services in these spheres; tourism } \\
- \text { hotels, catering, administrative activity and other related additional } \\
\text { services (tourist agencies and other organizations providing touristic } \\
\text { services). } \\
\text { Non-perspective economic specialization critically important for the } \\
\text { region's economy: mining. }\end{array}$ \\
\hline
\end{tabular}




\begin{tabular}{|c|c|c|}
\hline 3 & $\begin{array}{l}\text { Krasnodar } \\
\text { region }\end{array}$ & $\begin{array}{l}\text { Perspective economic specialization: motor vehicles production, trailers } \\
\text { and semi-trailers (except for the production of motor vehicles); production } \\
\text { of coke and petroleum products; production of computors, optical and } \\
\text { electronic goods; the production of medicines and materials used for } \\
\text { medical purposes; machines and equipment production, that are not } \\
\text { included in other groupings; metallurgy; drinks production; food } \\
\text { production; production of other non-metal mineral products; other finished } \\
\text { goods production; production of other vehicles and equipment; chemicals } \\
\text { and chemical products production; rubber and plastic items production; } \\
\text { electrical equipment production; crop and livestoc, providing services in } \\
\text { these spheres; information and communication activity; professional, } \\
\text { scientific and technical activity; healthcare and social services (health } \\
\text { resort organizations); transportation and storage; tourism. }\end{array}$ \\
\hline 4 & $\begin{array}{l}\text { Astrakhan } \\
\text { region }\end{array}$ & $\begin{array}{l}\text { Perspective economic specialization: mining; finished metal goods } \\
\text { production, except machines and equipment; leather and leather items } \\
\text { production; production of coke and petroleum products; production of } \\
\text { computors, optical and electronic goods; machines and equipment } \\
\text { production, that are not included in other groupings; drinks production; } \\
\text { food production; production of other non-metal mineral products; other } \\
\text { finished goods production; production of other vehicles and equipment; } \\
\text { rubber and plastic items production; textile goods production; chemicals } \\
\text { and chemical products production; electrical equipment production; crop } \\
\text { and livestoc, providing services in these spheres; fishing and fish farming; } \\
\text { information and communication activity; professional, scientific and } \\
\text { technical activity; transportation and storage; tourism. }\end{array}$ \\
\hline 5 & $\begin{array}{l}\text { Volgograd } \\
\text { region }\end{array}$ & $\begin{array}{l}\text { Perspective economic specialization: mining; motor vehicles production, } \\
\text { trailers and semi-trailers; finished metal goods production, except } \\
\text { machines and equipment; leather and leather items production; production } \\
\text { of coke and petroleum products; production of computors, optical and } \\
\text { electronic goods; the production of medicines and materials used for } \\
\text { medical purposes; machines and equipment production, that are not } \\
\text { included in other groupings; furniture production; metallurgy; drinks } \\
\text { production; food production; production of other non-metal mineral } \\
\text { products; other finished goods production; rubber and plastic items } \\
\text { production; other vehicles and equipment manufacture; tobacco products; } \\
\text { textile goods production; chemicals and chemical products production; } \\
\text { electrical equipment production; crop and livestoc, providing services in } \\
\text { these spheres; crop and livestoc, providing services in these spheres; } \\
\text { information and communication activity; professional, scientific and } \\
\text { technical activity; transportation and storage; tourism. }\end{array}$ \\
\hline
\end{tabular}




\section{Spatial Transformation as an Institutional Factor of the Public Management of Macroeconomic Systems}

\begin{tabular}{|c|c|c|}
\hline 5 & $\begin{array}{l}\text { Rostov } \\
\text { region }\end{array}$ & $\begin{array}{l}\text { Perspective economic specialization: motor vehicles production, trailers } \\
\text { and semi-trailers (except for the production of motor vehicles); paper and } \\
\text { paper products production; finished metal goods production, except } \\
\text { machines and equipment; leather and leather items production; production } \\
\text { of coke and petroleum products; } \\
\text { production of computors, optical and electronic goods; the production of } \\
\text { medicines and materials used for medical purposes; machines and } \\
\text { equipment production, that are not included in other groupings; furniture } \\
\text { production; metallurgy; drinks production; clothes production; food } \\
\text { production; production of other non-metal mineral products; other finished } \\
\text { goods production; rubber and plastic items production; other vehicles and } \\
\text { equipment manufacture; tobacco products; textile goods production; } \\
\text { chemicals and chemical products production; electrical equipment } \\
\text { production; crop and livestoc, providing services in these spheres; fishing } \\
\text { and fish farming; information and communication activity; professional, } \\
\text { scientific and technical activity; transportation and storage; tourism. }\end{array}$ \\
\hline 7 & $\begin{array}{l}\text { Republic of } \\
\text { Crimea }\end{array}$ & $\begin{array}{l}\text { Perspective economic specialization: finished metal goods production, } \\
\text { except machines and equipment; leather and leather items production; } \\
\text { production of computors, optical and electronic goods; the production of } \\
\text { medicines and materials used for medical purposes; machines and } \\
\text { equipment production, that are not included in other groupings; drinks } \\
\text { production; clothes production; food production; other finished goods } \\
\text { production; production of other non-metal mineral products; production of } \\
\text { other vehicles and equipment; rubber and plastic items production; } \\
\text { chemicals and chemical products production; electrical equipment } \\
\text { production; crop and livestoc, providing services in these spheres; fishing } \\
\text { and fish farming; information and communication activity; professional, } \\
\text { scientific and technical activity; healthcare and social services (health } \\
\text { resort organizations); transportation and storage; tourism. } \\
\text { Non-perspective economic specialization critically important for the } \\
\text { region's economy: mining. }\end{array}$ \\
\hline 8 & $\begin{array}{l}\text { Sevastopol, } \\
\text { the city of } \\
\text { federal } \\
\text { importance }\end{array}$ & $\begin{array}{l}\text { Perspective economic specialization: motor vehicles production, trailers } \\
\text { and semi-trailers (except for the production of motor vehicles); finished } \\
\text { metal goods production, except machines and equipment; machines and } \\
\text { equipment production, that are not included in other groupings; production } \\
\text { of computors, optical and electronic goods; drinks production; food } \\
\text { production; production of other non-metal mineral products; other finished } \\
\text { goods production; production of other vehicles and equipment; electrical } \\
\text { equipment production; crop and livestoc, providing services in these } \\
\text { spheres; fishing and fish farming; information and communication activity; } \\
\text { professional, scientific and technical activity; transportation and storage. }\end{array}$ \\
\hline
\end{tabular}




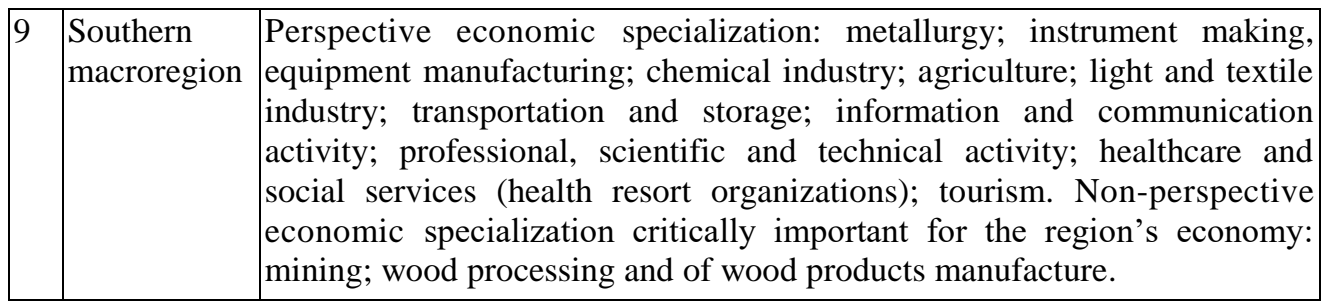

As it is clear from Table 1 the Southern macro-region's sub-regions have similar specializations. What is more, all regions have such specialization as transportation and storage. In general, it corresponds to the transit role of the macro-region in the country's economy.

In this connection the spatial transformation ongoing in the country makes the macro-region boost the efficiency of its transport and logistics framework. And tourism is represented in almost all regions; there are all favorable natural and climatic conditions, historically formed recreational potential, including unique balneological resources to ensure both good rest and healthcare. At the same time strategy of spatial development of the Russian Federation notes the preservation of sections with limited capacity on the main railways and highways of the transport corridors "West - East" and "North - South", including the sections on the federal highways of the southern regions of the European parts of the country. The low rates of the high-speed traffic network development are preserved. In general, it impedes the implementation of the transit potential of the Southern macro-region and its constituents, and it restricts the development of their other specializations. To solve these problems, it is necessary to unite and synchronize strategies and state programs of these subjects at the "supra-regional" level.

SWOT analysis of the social and economic system of the Southern macro-region shows the following Figure 2. Geostrategic location, advantageous natural and climatic conditions to develop agriculture, unique natural and climatic conditions promoting tourist industry, mineral reserves, high level of human capital and innovative potential are the "Strengths" of the social and economic system of the South of Russia. Also, good possibilities for social and economic system of the South of Russia to function and to develop should be mentioned. "Weaknesses" low competitiveness of products, security issues. "Opportunities" due to the cooperation at regional, national and international levels implementation of the major projects to achieve cooperation synergistic effect; transit and transport functions performance; international links development and joint ventures setting up. "Threads" low quality of products, sectorial imbalances etc. 


\section{Spatial Transformation as an Institutional Factor of the Public Management of Macroeconomic Systems}

Figure 2. Visual presentation of the matrix of the SWOT analysis of the functioning and development of the social and economic macro-systems of the South of Russia (Dimitriadi et al., 2018)

\begin{tabular}{|c|c|}
\hline $\begin{array}{l}\text { "Strengths" - strong points of the social } \\
\text { and economic development of the macro- } \\
\text { systems of the South of Russia }\end{array}$ & $\begin{array}{l}\text { "Weaknesses" - week points of the social } \\
\text { and economic development of the macro- } \\
\text { systems of the South of Russia }\end{array}$ \\
\hline $\begin{array}{l}\text { 1. Geopolitical position } \\
\text { 2. Natural and climatic conditions and } \\
\text { resources available } \\
\text { 3. } \begin{array}{l}\text { Human capital and innovation } \\
\text { potential }\end{array}\end{array}$ & $\begin{array}{l}\text { 1. Low competitiveness of products and } \\
\text { technologies } \\
\text { 2. Social and demographic problems } \\
\text { 3. Security issues }\end{array}$ \\
\hline $\begin{array}{l}\text { "Opportunities" to function and develop } \\
\text { the social and economic development of } \\
\text { the macro-systems of the South of Russia }\end{array}$ & $\begin{array}{l}\text { "Threats" to functioning and developing the } \\
\text { social and economic development of the } \\
\text { macro-systems of the South of Russia }\end{array}$ \\
\hline $\begin{array}{l}\text { 1. Opportunities to cooperate at regional, } \\
\text { national and international levels } \\
\text { 2. Opportunities to increase the } \\
\text { investment attractiveness } \\
\text { Opportunities to maximize the } \\
\text { advantages of the geoeconomic and } \\
\text { strategic position, natural and climatic } \\
\text { conditions and territories } \\
\text { 4. Opportunities to use the potential of } \\
\text { functioning and development of the } \\
\text { social and economic system based on } \\
\text { the human cognitive activity }\end{array}$ & $\begin{array}{l}\text { 1. Threats caused by low } \\
\text { quality of some products } \\
\text { 2. Threats due to sectorial } \\
\text { imbalances } \\
\text { 3. Threats of demographic } \\
\text { nature } \\
\text { 4. Risk of ecological and } \\
\text { technogenic problems }\end{array}$ \\
\hline
\end{tabular}

To maximize the advantages of the geo-economic and strategic position, natural and climatic conditions and territory of the Southern macro-region is to be supported by the federal center while implementing major infrastructural projects, including "supra-regional projects" implementation management.

\section{Conclusions and Recommendations}

The proposed approach to the public administration of the social and economic development of the macro-regions is based on all above-mentioned specific features, inherent to these territorial entities in the system of the administrative and territorial division of the Russian Federation. The key signs of the macro-regional social and economic systems, the Federal Districts in Russia, namely intermediate position between federal and regional levels of the public administration, integration due to the RF subjects (regions) constituting it, its own spatial and economic role in the national system of the territorial labor division means that macro-regional 
management can be and must be considered as management of the interaction of the regions constituting the macro-regions while solving the "supra-regional" problems. Among these issues are those related to the creation or improving of the major supra-regional projects whose implementation requires resources (both financial and territorial, labor, intellectual, scientific and research, etc.) of two or more regions of the macro-region system. While implementing these projects different number of regions can be involved, and besides the representatives of the interested regional authorities, other alternative interested parties can exist (large trans-regional business, natural monopolies, large construction companies, banks, specializing in large infrastructural project financing, energy companies, etc.)

Taking this into account the macro-region management system is to be flexible enough to respond the number of participants, those influencing the decision taking on certain projects and their coordination with inner region stake holders and strategic documents. Thus, the system of the public administration of the macro-regions is to be based on the principle of formation of the temporary working groups, each of which is consisting of the representatives of the corresponding federal bodies and regional authorities and other stakeholders. These groups exist while the "supra-regional" project is being implemented. The structure of such a working group is presented in the following Figure 3.

In accordance with the presented scheme the public administration system is to be realized through a set of "supra-regional" projects to meet the needs of the spatial development of the country at a whole, on the one hand, and internal potential of the RF subjects constituting the macro-region, on the other. Such an approach allows ensuring the more effective implementation by the macroregion and its regions their spatial and economic role in the national economic system. Thus, the public administration at the macro-regional level can be reduced to the implementation of several certain projects. In this case it will be enough easy to identify the management performance which can be assessed in terms of achievement of certain results (for example, construction of roads in a single transport and logistic system).

The positive aspect of the proposed scheme is the use of the already existing managerial structures and the resources of the federal and regional levels without developing new rigid structures at the level of the macro-region. The main principle is to set temporary working groups formed to implement the certain project, the group is dismissed as soon as the project finished, and its participants can be regrouped for new projects. 


\section{Spatial Transformation as an Institutional Factor of the Public Management}

of Macroeconomic Systems

Figure 3. The proposed scheme of the macro-region public administration with applying the principles of public management (designed by the authors).

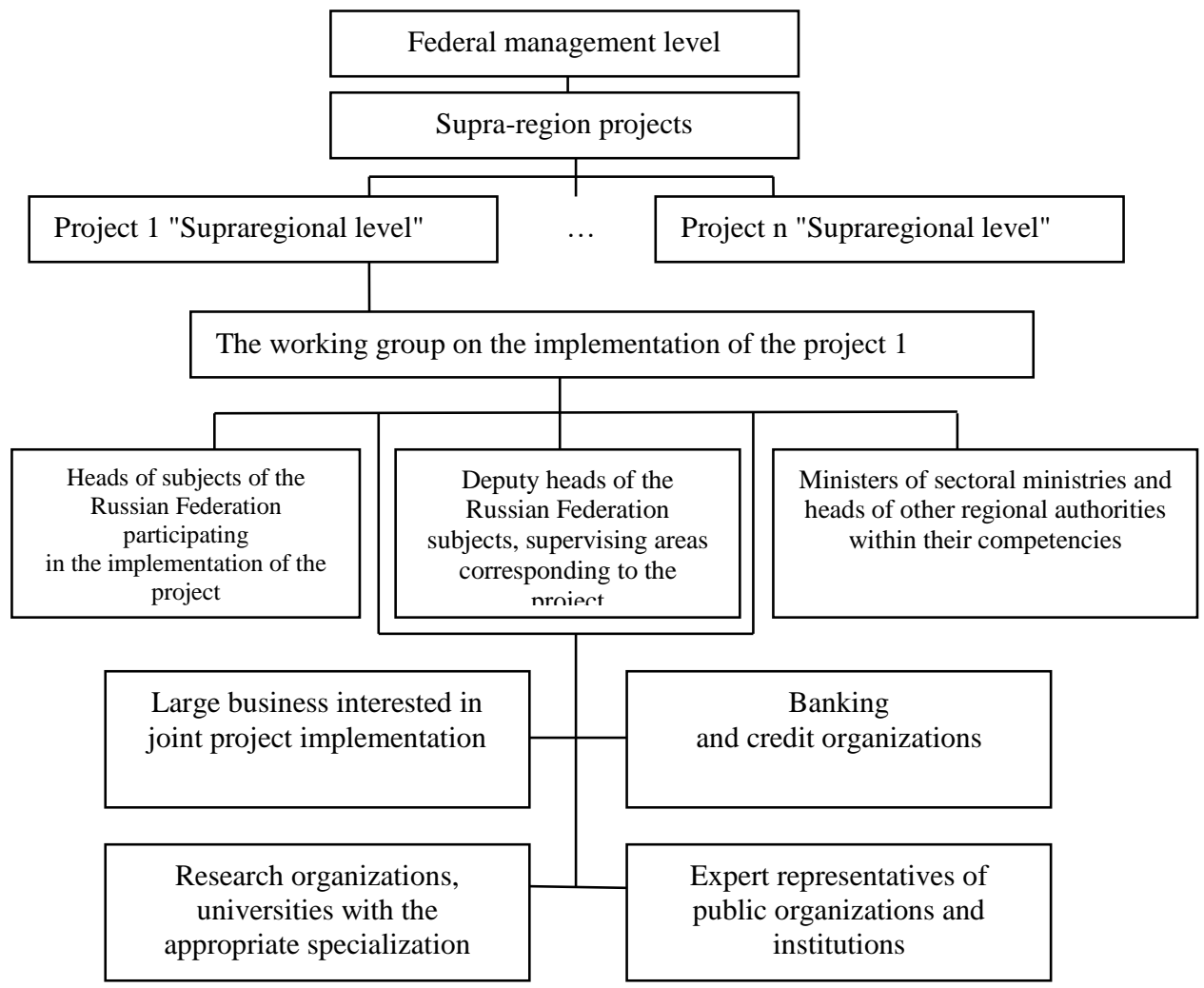

Besides, the proposed scheme allows uniting the efforts and resources of the different regions of the macro-regional system of different "supra-regional" projects depending on the degree of the territorial involvement as well as the availability of internal resources and the need of certain regions to participate in such projects. It will also allow the regions to increase the level if the interregional interaction, to interact with the federal structures, to compete effectively for additional federal resources, and will allow the federal structures to get feedback. Principles of publicity and openness, necessary to implement the public management models, while applying this approach are also necessary to organize the successful work of such groups. It is proposed to design the specialized open access sites allowing getting the on-line information on the projects to be implemented, the stages and results. It is also necessary to collect and process the information obtained from the public on the need of the projects to be implemented (at the pre-project stage). When taking a decision on the 
project implementation all information on the process of the achieving the goals, intermediate results and other useful information on the accumulated positive experience is to be delivered for all concerned.

\section{References:}

Belyakova, G., Dulesov, A., Konyakina, T. 2018. Import substitution issues in the modern economy. Fundamental Researches, 9, 25-31.

Danilina, M.P. 2017. Activity of associations of economic interaction of the Russian Federation subjects in the framework of the integration of the regions. Bulletin of the National State University of Economics and Industry, 2, 235-242.

Dimitriadi, N.A., Ivanova, E.A., Voskanov, M.E., Brelik, A. 2018. The Priority Choice in the Process of Strategy Working-out of the Social Economic Micro Region Development. European Research Studies Journal, S2(21), 46-52.

Gerasimov, A., Gromov, E., Pshenichny, P. 2011. Diagnostics of the economic management system effectiveness in a macro-region. Publishing house "AGRUS", Stavropol, 28.

Ivanov, A. 2012. Economic space of the macro-region: methodological aspects of foreign economic activity. News of the Volgograd State Technical University, 16(103), 156161.

Ivanova, T., Kleitman, A., Kirsanov, M. 2016. Macro-regions formation in the context of the experience of economic zoning of the 1920s (on the example of the Lower Volga region). Management of economic systems: electronic scientific journal, 10(92), 11.

Koroleva, E.N., Ovsyannikova, R.V., Sharkevich, E.A. 2015. Macro-regions in the strategic planning system: object identification and modern practice of goal setting. Regional development: an electronic scientific journal, 5(9), URL:

https://regrazvitie.ru/makroregiony-v-sisteme-strategicheskogo-planirovaniyaidentifikatsiya-obekta-i-sovremennaya-praktika-tselepolaganiya/.

Kuklina, L., Ponomareva, S. 2012. New macroeconomic model of the national economy. Economy of the region, 1, 253-259.

Kurushina, E., Petrov, M. 2018. Criteria for the spatial development projects success based on inter-regional integration. Economy of the region, 1(14), 176-189.

Lokosov, V., Ryumina, E., Ulyanov, V. 2018. Russia's Macro-regions: Characteristics of Human Potential, Population, 3(21), 37-51.

Popov, P., Saraev, V. 2016. Comparison of Siberia with other macro-regions of the Russian Federation in terms of development and social well-being. Advances in Current Natural Sciences, 9, 160-171.

Reshiev, S. 2009. The choice of adequate methods of state regulation and stimulating the macro-region development. Regional economy: theory and practice, 11(104), 9-17.

Suslov V.I. 2017. Problems and scenarios of the spatial development of Russia. Economy of the East of Russia, 1(7), 47-51.

Tsvetkova, O.V. 2016. Cross-border cooperation of the border regions of the Russian Federation. PolitBook, 4, 96-107.

Zubarevich, N.V. 2019. Spatial Development Strategy: Priorities and Tools. Voprosy Ekonomiki, 1, 135-145. 